\title{
STRATEGIC RELATIONSHIP MARKETING LEADS TO THE SUCCESS OF INSURANCE BUSINESSES IN
} THAILAND

Nasi Chuwiruch, Mahasarakham Business School, Mahasarakham University, Thailand Phapruke Ussahawanitchakit, Mahasarakham Business School, Mahasarakham University, Thailand

\author{
dx.doi.org/10.18374/IJBR-13-3.5
}

\begin{abstract}
Recently, the importance of long-term relationships with customers is realized, especially by business firms such as insurance companies. The objective of this paper is to examine the relationships among strategic relationship marketing and its antecedents and consequences. By data collected from the insurance businesses in Thailand, the impact of the four relationship marketing strategies on the outcomes including brand trust, customer commitment, market reliability, and market success are investigated. The relationships among the strategic relationship marketing dimensions and the antecedents, namely, market driving vision, partnership mindset, collaboration experience, environmental changes, and market knowledge, are also examined. The results indicate that the fundamental aspects of market success of insurance businesses in Thailand are customer commitment and market reliability. The findings also show that personalization and communication are two key strategies that can lead insurance firms to market success. In addition, the market driving vision of managers is found to be a key factor that can enhance the implementation of strategic relationship marketing. Finally, the contributions and suggestions for future research as well as conclusion are presented.

Keywords: Strategic Relationship Marketing, Marketing Strategy, Preferential Treatment, Communication, Rewarding Program, Personalization, Brand Trust, Customer Commitment, Market Reliability, Market Success, Market Driving Vision, Partnership Mindset, Collaboration Experience, Market Knowledge, Environmental Changes, Insurance Business
\end{abstract}

